Original Research Article

\title{
Revalorization of Tunisian wild Amaranthaceae halophytes: Nutritional composition variation at two different phenotypes stages
}

\author{
Mariem Maatallah Zaier ${ }^{\mathrm{a}, \mathrm{b}}$, María Ciudad-Mulero ${ }^{\mathrm{b}}$, Montaña Cámara ${ }^{\mathrm{b}}$, Carla Pereira $^{\mathrm{c}}$, \\ Isabel C.F.R. Ferreira ${ }^{c}$, Lotfi Achour ${ }^{\mathrm{a}}$, Adnen Kacem ${ }^{\mathrm{a}}$, Patricia Morales ${ }^{\mathrm{b}, *}$ \\ a Laboratoire de Recherche Bioressources: Biologie Intégrative \& Valorisation, Institut Supérieur de Biotechnologie de Monastir, Université de Monastir, Monastir, Tunisia \\ ${ }^{\mathrm{b}}$ Nutrition and Food Science Department, Pharmacy Faculty, Complutense University of Madrid (UCM). Pza Ramón y Cajal, s/n. E-28040, Madrid, Spain \\ ${ }^{\mathrm{c}}$ Centro de Investigação de Montanha (CIMO), Instituto Politécnico de Bragança, Campus de Santa Apolónia, 5300-253 Bragança, Portugal
}

\section{A R T I C L E IN F O}

\section{Keywords:}

Wild shoots

Nutritional profile

Dietary fiber

Minerals

Fatty acids profile

Vitamin C

Vitamin E

\begin{abstract}
A B S T R A C T
Wild halophytes are traditionally consumed in Tunisia as gourmet vegetables due to their salty taste and organoleptic proprieties. However, their nutritional composition is not deeply studied. The aim of this study was to characterize three Tunisian wild halophytic species (Arthrocnemum indicum (Willd.) Moq, Halocnemum strobilaceum (Pall.) M. Bieb., and Suaeda fruticosa Forssk) at two different phenotypic stages according to the seasonal variation. Amaranthaceae, is one of the well spread halophytes family shrubs in the world, mainly in Mediterranean countries. The studied wild halophytes are an interesting source of nutrients and could be considered as healthy foods with high levels of dietary fibers (7.63-10.14 g/100 g fw), protein $(2.45-4.14 \mathrm{~g} / 100 \mathrm{~g}$ $\mathrm{fw}), \mathrm{n}-3$ polyunsaturated fatty acids in green phenotypic stage (29.87 \%-40.5 \%) and n-6 polyunsaturated fatty acids in red-violet phenotypic stage (25.4\%-75.26\%), with particular relevance to linolenic acid content (20.7 $\%-75.22 \%)$. These halophytes are also a good source of minerals, particularly sodium, calcium, potassium and magnesium, as well as vitamins $\mathrm{C}$ and $\mathrm{E}$, with a major abundance of $\alpha$-tocopherol.
\end{abstract}

\section{Introduction}

Wild halophyte plants have been traditionally used since ancient times in different areas worldwide. Nowadays, it is known that halophytes present several biomolecules with associated health and nutritional benefits. For this reason, there is a growing interest, including economic interest in the study and crop of halophyte plants (Abdelly et al., 2006; Cheeseman, 2013; Hasanuzzaman et al., 2014; Ksouri et al., 2012; Qasim, 2011). Chenopodiaceae family, also known as Amaranthaceae, is the most important halophytes family, being Salicornia species (with the common names of glasswort or Hamcho) the most relevant ones. These species have been used as traditional food and in folk medicine in many different regions, particularly in Mediterranean countries such as Tunisia, several European coastal countries, Asian and SouthAmerican regions (Guarrera et al., 2006; Kim et al., 2006; Zaruyk \& Baalbaki, 1996; Zhu \& Row, 2010). Recently, different researchers have focused their attention in the study of the nutritional composition of Salicornia sp. and it has been confirmed that these plants area good source of essential minerals, dietary fibers, fatty acids, vitamins, tocopherols, and natural pigments (Barreira et al., 2017; Ksouri et al., 2012).
From an ecophysiological point of view, vegetables are fixed organisms highly influenced by environmental fluctuations. In Tunisia, as in other Mediterranean countries, the two major factors responsible for the crop productivity limitation and the alteration of vegetation mosaic are drought and salinity (Cheeseman, 2013; Slama et al., 2015). Plants need to be adapted to these conditions and, in this sense, extremophile species live in hard biotopes with drought and high temperatures, as well as long ultraviolet radiation that causes excessive salt accumulation and generates real plants damage (Lokhande \& Suprasanna, 2012; Slama et al., 2015).

Salt-tolerant plants have to develop different strategies to survive under hard stress environments that threaten their growth. In this sense, shoots of some Amaranthaceae halophyte species change their colour from green to red-violet as part of their adaptation approach (Hayakawa \& Agarie, 2010; Zhao et al., 2011).

As far as we know, there are no previous studies regarding the nutritional profile in different physiological stages by comparing two seasonal phenotypes (green and red-violet shoots) of the studied halophyte species. Therefore, the aim of this study was to evaluate the nutritional profile of young shoots of three wild Amaranthaceae halophytes (Arthrocnemum indicum (Willd.) Moq, Halocnemum strobilaceum

\footnotetext{
* Corresponding author.

E-mail address: patricia.morales@farm.ucm.es (P. Morales).
} 
(Pall.) M. Bieb., and Suaeda fruticosa Forssk.) in two different phenotypic stages, in order to revalorize these wild halophyte species and promote their crop adaptation for culinary uses, especially in arid and semi-arid regions all over the world, where the global warming and the drought seriously threaten the agriculture productivity and compromise food security.

\section{Material and methods}

\subsection{Plant material}

Young shoots of three wild Tunisian halophytes, namely Arthrocnemum indicum(Willd.) Moq., Halocnemum strobilaceum (Pall.) M. Bieb., and Suaeda fruticosa Forssk. were collected in two phenotypic stages (green and red-violet) from Sebkha of Sidi el Heni, located in southwest of Sousse (Tunisia) between March and August 2017. The taxonomical identification of species was done by Dr. Abderrazek Smaoui at the Center of Biotechnology of Borj Cedria (Laboratory of Extremophile Plants). For nutritional analysis, after collection, fresh shoots were freeze-dried and stored at $-20^{\circ} \mathrm{C}$ until analysis.

\subsection{Nutritional composition}

\subsubsection{Proximate composition}

Moisture, ash, total fat and crude protein contents were determined according to AOAC methods (AOAC, 2000). Moisture was determined by desiccation to constant weight at $100 \pm 2{ }^{\circ} \mathrm{C}$; ashes were determined by incineration at $550 \pm 15^{\circ} \mathrm{C}$ until full organic fraction combustion; total proteins were determined as nitrogen content by the Kjeldahl method after digestion in sulphuric acid; and total fats were determined gravimetrically after a continuous extraction process with petroleum-ether using a Soxhlet system. All results were expressed as $\mathrm{g}$ / $100 \mathrm{~g}$ of fresh weight $(\mathrm{fw})$.

Total available carbohydrates (TAC) determination was carried out by a colorimetric method using anthrone reagent, after hydrolysis with $\mathrm{HClO}_{4}$, as described by Osborne \& Voogt (1986). Absorbance was measured at $630 \mathrm{~nm}$ on a UV/Vis Spectrometer EZ210 (Perkin Elmer, Waltham, MA, USA). A glucose curve was used as standard; TAC values were expressed as g glucose $/ 100 \mathrm{~g} \mathrm{fw}$.

Energy value of samples analysed was calculated according to the European Regulation No1169/2011 (European Parliament \& Council of the European Union, 2006) [1]:

Energy $(\mathrm{Kcal} / 100 \mathrm{~g} \mathrm{fw})=[4 \times(\mathrm{g}$ protein $+\mathrm{g}$ carbohydrate $)+2$ $\times(\mathrm{g}$ Total dietary fiber $)+9 \times \mathrm{g}$ fat $)][1]$

\subsubsection{Total, soluble and insoluble dietary fiber assay}

Total (TDF), soluble (SDF) and insoluble dietary fiber (IDF) content was analysed referring to AOAC enzymatic-gravimetric methods 993.19 and 991.42 (Latimer, 2012). Lyophilized shoots were treated with thermo-stable $\alpha$-amylase, protease, and amyloglucosidase, for protein and starch elimination. Temperature and time incubation were controlled.Vacuum filtration was used to separate soluble and insoluble fractions. The obtained residues were dried at $100{ }^{\circ} \mathrm{C}$ and the residue of proteins was analysed using the Kjeldahl equipment. Subsequently, TDF was calculated by the summation of SDFand IDF content and results were expressed as $\mathrm{g} / 100 \mathrm{~g} \mathrm{fw}$.

\subsubsection{Mineral composition (micro and macroelements)}

Total ashes determination and minerals analysis were carried out according the methodology described by Rodríguez et al. (2011). In brief, $500 \mathrm{mg}$ of each sample were incinerated at $550 \pm 15^{\circ} \mathrm{C}$. Then, an acid attack with $\mathrm{HCl}(50 \%)$ and $\mathrm{HNO}_{3}(50 \%)$ of residue was done and the volume was adjusted with distilled water to $25 \mathrm{~mL}$. Copper $(\mathrm{Cu})$, iron $(\mathrm{Fe})$, manganese $(\mathrm{Mn})$, and zinc $(\mathrm{Zn})$ were instantly measured using atomic spectrophotometer, following the procedure described by Rodríguez et al. (2011). In order to avoid interferences, additional solutions were prepared for the quantification of macroelements. Sodium $\left(\mathrm{Na}^{+}\right)$and potassium $\left(\mathrm{K}^{+}\right)$were measured in $\mathrm{CsCl}(0.2 \mathrm{~g} / 100 \mathrm{~g}$ solution), while magnesium $\left(\mathrm{Mg}^{2+}\right)$ and calcium $\left(\mathrm{Ca}^{2+}\right)$ measurement was carried out in $1.16 \mathrm{~g} \mathrm{La}_{2} \mathrm{O}_{3} / 100 \mathrm{~mL} \mathrm{HCl}$ solution (resulting $\mathrm{LaCl}_{2}$ ). Whole analysis was effectuated by atomic absorption spectroscopy (AAS) (Perkin Elmer. Waltham. MA. USA) by comparing absorbance responses with analytical standard solutions for AAS. The results were expressed in $\mathrm{mg} / 100 \mathrm{~g}$ of fresh weight (fw).

\subsubsection{Fatty acid profile}

Fatty acids (FA) were methylated and conditioned according to the procedure previously reported by Morales et al. (2013). Individual FA were determined by gas chromatography with flame ionization detection (GC-FID)/capillary column and identified comparing the relative retention times of FAME (fatty acid methyl esters) peaks from samples with standards. The results were recorded and processed using CSW Data Apex 1.7 software and expressed in relative percentage of each fatty acid.

\subsection{Vitamins content}

Vitamin C (ascorbic acid) analysis was performed by HPLC-UV according to the method already described by Morales et al. (2013). This vitamin was quantified by comparison of the area of its peak recorded with the calibration curves obtained from the pattern as standard. Results were expressed as $\mathrm{g} / 100 \mathrm{~g}$ of $\mathrm{fw}$.

Vitamin $E$ (tocopherols) identification was performed according to the method previously describedby Morales et al. (2012). Determination was carried out using HPLC and a fluorescence detector (FP-2020; Jasco, Easton, MD, USA). Excitation wavelength used was $290 \mathrm{~nm}$ and emission wavelength was $330 \mathrm{~nm}$. Quantification was based on the fluorescence indicative answering of each standard, using the internal standard (IS) (tocol) method and by using calibration curves acquired from commercial standards of each compound. The results were expressed in $\mathrm{mg} / 100 \mathrm{~g}$ of fw.

\subsection{Indexes of lipid quality}

Fatty acid (FA) ratio was calculated according to the equation used by Duarte et al.(2018), whereas the atherogenicity (AI) and thrombogenicity (TI) index were calculated based on the results of the fatty acid profile according to equations [2] and [3] used by Barreira et al. (2017) and the method previously used by Ulbricht and Southgate (1991).

\subsubsection{Index of atherogenicity (IA)}

$\mathrm{IA}=[\mathrm{C} 12: 0+(4 \mathrm{x} \quad \mathrm{C} 14: 0)+\mathrm{C} 16: 0] \quad /[\Sigma$ MUFA $+\Sigma$ PUFA n3 + EPUFA-n6][2].

This index represents the dealing between the main SFA, MUFA, and PUFA amounts.

\subsubsection{Index of thrombogenicity (IT)}

$\mathrm{IT}=(\mathrm{C} 14: 0+\mathrm{C} 16: 0+\mathrm{C} 18: 0) /(0.5 \times$ MUFA $+0.5 \times$ PUFA-n6 $+3 \mathrm{x}$ PUFA-n3 + PUFA) [3].

This index indicates the tendency of blood coagulation and clots risks. Actually, it's the correlation between the pro-thrombogenic (saturated) and the anti-thrombogenic FA(MUFAs, PUFAs - n6 and PUFAs $-\mathrm{n} 3)$.

\subsection{Statistical analysis}

For each species, triplicate independent samples were used. Results were expressed as mean values \pm standard deviation. All statistical tests were performed at a 5\% significance level using One Way ANOVA (SPSS version 22.0). With the obtained results, two different statistical analysis were performed: one to compared differences between all samples, and other to compare the main phenotypic stages for the same 
Table 1

Proximate composition ( $\mathrm{g}$ per $100 \mathrm{~g} \mathrm{fw}$ ) and mineral content (mg/100 g) of Tunisian halophyte species in two different phenotypic stages.

\begin{tabular}{|c|c|c|c|c|c|c|}
\hline \multirow{2}{*}{$\begin{array}{l}\text { Nutritional parameters } \\
(\mathrm{g} / 100 \mathrm{~g} \mathrm{fw})\end{array}$} & \multicolumn{2}{|c|}{ Arthrocnemum indicum } & \multicolumn{2}{|c|}{ Halocnemum strobilaceum } & \multicolumn{2}{|l|}{ Suaeda fruticosa } \\
\hline & Green & Red-violet & Green & Red-violet & Green & Red-violet \\
\hline Code & AP1 & AP2 & HP1 & HP2 & SP1 & SP2 \\
\hline Moisture & $80.1 \pm 2.5^{\mathrm{e}, \mathrm{A}}$ & $79.3 \pm 3.0^{\mathrm{d}, \mathrm{A}}$ & $77.4 \pm 2.1^{\mathrm{c}, \mathrm{A}}$ & $76.0 \pm 1.2^{\mathrm{c}, \mathrm{A}}$ & $74.4 \pm 0.8^{\mathrm{b}, \mathrm{A}}$ & $73.2 \pm 0.4^{\mathrm{a}, \mathrm{A}}$ \\
\hline Total ash & $3.0 \pm 0.4^{\mathrm{cd}, \mathrm{A}}$ & $3.4 \pm 0.2^{\mathrm{c}, \mathrm{A}}$ & $6.4 \pm 0.0^{\mathrm{b}, \mathrm{A}}$ & $7.4 \pm 0.5^{\mathrm{a}, \mathrm{B}}$ & $2.7 \pm 0.0^{\mathrm{d}, \mathrm{B}}$ & $2.5 \pm 0.1^{\mathrm{d}, \mathrm{A}}$ \\
\hline Crude proteins & $3.1 \pm 0.5^{\mathrm{c}, \mathrm{B}}$ & $2.5 \pm 0.1^{\mathrm{d}, \mathrm{A}}$ & $3.3 \pm 0.1^{\mathrm{c}, \mathrm{A}}$ & $3.0 \pm 0.1^{\mathrm{b}, \mathrm{A}}$ & $4.4 \pm 0.2^{\mathrm{a}, \mathrm{B}}$ & $3.1 \pm 0.1^{\mathrm{c}, \mathrm{A}}$ \\
\hline Total fat & $2.6 \pm 0.3^{\mathrm{d}, \mathrm{A}}$ & $2.6 \pm 0.1^{\mathrm{d}, \mathrm{A}}$ & $3.3 \pm 0.2^{\mathrm{c}, \mathrm{B}}$ & $2.4 \pm 0.1^{\mathrm{d}, \mathrm{A}}$ & $4.9 \pm 0.3^{\mathrm{b}, \mathrm{A}}$ & $6.0 \pm 0.3^{\mathrm{a}, \mathrm{B}}$ \\
\hline Total available carbohydrate & $2.4 \pm 0.1^{\mathrm{d}, \mathrm{A}}$ & $3.2 \pm 0.3^{\mathrm{c}, \mathrm{B}}$ & $2.6 \pm 0.3^{\mathrm{d}, \mathrm{A}}$ & $3.1 \pm 0.3^{\mathrm{c}, \mathrm{A}}$ & $4.1 \pm 0.1^{\mathrm{a}, \mathrm{A}}$ & $3.7 \pm 0.3^{\mathrm{b}, \mathrm{A}}$ \\
\hline Total dietary fiber & $10.0 \pm 0.9^{\mathrm{b}, \mathrm{A}}$ & $10.1 \pm 0.6^{\mathrm{bc}, \mathrm{A}}$ & $7.3 \pm 0.5^{\mathrm{d}, \mathrm{A}}$ & $9.1 \pm 0.5^{\mathrm{c}, \mathrm{B}}$ & $10.1 \pm 0.5^{\mathrm{bc}, \mathrm{A}}$ & $12.0 \pm 0.8^{\mathrm{a}, \mathrm{B}}$ \\
\hline Insoluble dietary fiber & $6.9 \pm 0.7^{\mathrm{ab}, \mathrm{A}}$ & $7.6 \pm 0.4^{\mathrm{ab}, \mathrm{A}}$ & $5.9 \pm 0.4^{\mathrm{c}, \mathrm{A}}$ & $8.0 \pm 0.6^{\mathrm{a}, \mathrm{B}}$ & $6.8 \pm 0.4^{\mathrm{bc}, \mathrm{A}}$ & $7.6 \pm 0.9^{\mathrm{ab}, \mathrm{A}}$ \\
\hline Soluble dietary fiber & $3.1 \pm 0.4^{\mathrm{b}, \mathrm{A}}$ & $2.5 \pm 0.4^{\mathrm{c}, \mathrm{A}}$ & $1.4 \pm 0.4^{\mathrm{c}, \mathrm{A}}$ & $1.1 \pm 0.1^{\mathrm{cd}, \mathrm{A}}$ & $3.4 \pm 0.5^{\mathrm{b}, \mathrm{A}}$ & $4.5 \pm 0.4^{\mathrm{a}, \mathrm{B}}$ \\
\hline$\% \mathrm{IDF} / \mathrm{TDF}$ & $68.6 \pm 2.1^{\mathrm{d}, \mathrm{A}}$ & $74.9 \pm 6.6^{\mathrm{c}, \mathrm{A}}$ & $80.6 \pm 5.1^{\mathrm{b}, \mathrm{A}}$ & $87.7 \pm 1.7^{\mathrm{a}, \mathrm{B}}$ & $67.0 \pm 3.9^{\mathrm{d}, \mathrm{A}}$ & $63.4 \pm 2.8^{\mathrm{e}, \mathrm{A}}$ \\
\hline Energy (kcal/100 g fw) & $64.1^{\mathrm{b}, \mathrm{A}}$ & $66.4^{\mathrm{c}, \mathrm{B}}$ & $68.4^{\mathrm{d}, \mathrm{B}}$ & $63.8^{\mathrm{a}, \mathrm{a}}$ & $97.7^{\mathrm{e}, \mathrm{A}}$ & $105.4^{\mathrm{f}, \mathrm{B}}$ \\
\hline \multicolumn{7}{|l|}{ Mineral content $(\mathrm{mg} / 100 \mathrm{~g} \mathrm{fw})$} \\
\hline $\mathrm{Fe}$ & $0.47 \pm 0.01^{\mathrm{f}, \mathrm{B}}$ & $0.29 \pm 0.02^{\mathrm{c}, \mathrm{A}}$ & $0.30 \pm 0.03^{\mathrm{d}, \mathrm{A}}$ & $0.45 \pm 0.02^{\mathrm{e}, \mathrm{B}}$ & $0.09 \pm 0.01^{\mathrm{a}, \mathrm{A}}$ & $0.13 \pm 0.01^{\mathrm{b}, \mathrm{B}}$ \\
\hline $\mathrm{Cu}$ & $0.29 \pm 0.01^{\mathrm{b}, \mathrm{A}}$ & $0.29 \pm 0.01^{\mathrm{b}, \mathrm{A}}$ & $0.71 \pm 0.07^{\mathrm{d}, \mathrm{B}}$ & $0.48 \pm 0.01^{\mathrm{c}, \mathrm{A}}$ & $0.19 \pm 0.02^{\mathrm{a}, \mathrm{A}}$ & $0.29 \pm 0.01^{\mathrm{b}, \mathrm{B}}$ \\
\hline Mn & $0.11 \pm 0.01^{\mathrm{b}, \mathrm{A}}$ & $0.16 \pm 0.01^{\mathrm{c}, \mathrm{B}}$ & $0.28 \pm 0.01^{\mathrm{e}, \mathrm{A}}$ & $0.34 \pm 0.02^{\mathrm{f}, \mathrm{B}}$ & $0.09 \pm 0.01^{\mathrm{a}, \mathrm{A}}$ & $0.18 \pm 0.01^{\mathrm{d}, \mathrm{B}}$ \\
\hline $\mathrm{Zn}$ & $0.48 \pm 0.01^{\mathrm{b}, \mathrm{B}}$ & $0.17 \pm 0.01^{\mathrm{a}, \mathrm{A}}$ & $0.19 \pm 0.01^{\mathrm{a}, \mathrm{A}}$ & $0.76 \pm 0.09^{\mathrm{d}, \mathrm{B}}$ & $0.56 \pm 0.02^{\mathrm{c}, \mathrm{A}}$ & $0.55 \pm 0.05^{\mathrm{c}, \mathrm{A}}$ \\
\hline $\mathrm{Mg}$ & $55.91 \pm 0.08^{\mathrm{a}, \mathrm{A}}$ & $59.37 \pm 0.33^{\mathrm{b}, \mathrm{B}}$ & $62.30 \pm 4.85^{\mathrm{c} . \mathrm{A}}$ & $72.52 \pm 0.36^{\mathrm{d}, \mathrm{B}}$ & $74.73 \pm 0.42^{\mathrm{de}, \mathrm{A}}$ & $77.12 \pm 2.24^{\mathrm{e}, \mathrm{B}}$ \\
\hline $\mathrm{Ca}$ & $109.50 \pm 4.28^{\mathrm{c}, \mathrm{B}}$ & $80.07 \pm 0.30^{\mathrm{a}, \mathrm{A}}$ & $104.96 \pm 6.77^{\mathrm{bc}, \mathrm{A}}$ & $174.92 \pm 12.93^{\mathrm{d}, \mathrm{B}}$ & $73.79 \pm 2.18^{\mathrm{a}, \mathrm{A}}$ & $99.87 \pm 8.39^{\mathrm{b}, \mathrm{B}}$ \\
\hline $\mathrm{Na}$ & $233.55 \pm 18.55^{\mathrm{c}, \mathrm{B}}$ & $122.01 \pm 3.41^{\mathrm{b}, \mathrm{A}}$ & $251.97 \pm 22.66^{\mathrm{d}, \mathrm{A}}$ & $518.62 \pm 23.73^{\mathrm{e}, \mathrm{B}}$ & $84.63 \pm 2.38^{\mathrm{a}, \mathrm{A}}$ & $94.21 \pm 9.24^{\mathrm{a}, \mathrm{B}}$ \\
\hline $\mathrm{K}$ & $32.81 \pm 0.17^{\mathrm{b}, \mathrm{B}}$ & $28.31 \pm 1.43^{\mathrm{a}, \mathrm{A}}$ & $35.39 \pm 2.36^{\mathrm{cd}, \mathrm{A}}$ & $43.05 \pm 1.69^{\mathrm{e}, \mathrm{B}}$ & $36.13 \pm 0.49^{\mathrm{d}, \mathrm{B}}$ & $33.65 \pm 2.10^{\mathrm{bc}, \mathrm{A}}$ \\
\hline
\end{tabular}

Results are presented as mean \pm SD. In each row, different letters mean statistically significant differences $(\mathrm{p}<0.05)$ compared by Tukey test; small superscript letters mean differences between all samples, whereas capital superscript letters mean difference due to the phenotypic stage (P1 and P2) for the same species.

specie, in order to identify the phenotypic stage with the best nutritional profile for each studied halophyte. Moreover, multivariable analysis, canonical correlations and principal components analysis (PCA), were performed among the variables analysed using Statgraphics Plus 5.1 software.

\section{Results and discussion}

\subsection{Nutritional parameters}

The results of the proximate composition of the analysed wild halophytes, expressed in $\mathrm{g} / 100 \mathrm{~g}$ fw, were shown in Table 1 . As previoulsy mentioned, halophytes are continuously exposed to hard environment conditions such as high soil salinity concentration, drought, excessive temperature and long exhibition to ultraviolet radiation (Flowers \& Colmer, 2008; Hameed \& Khan, 2011). These plants have developed several tactics to survive, adapting their physiological system with the aim of preserving the intracellular ionic balance and protect the chloroplasts, membrane lipids, proteins, and nucleic acids, that are highly affected by oxidative processes (Munns \& Tester, 2008; Zhu, 2002). This approach can explain the fluctuation of their nutritional profile proportionally with their environment alteration.

In the present study, three wild Tunisian halophytes were characterized in terms of their nutritional value (proximate composition, minerals, fatty acids, and some vitamins). Moreover, each species was evaluated in two different phenotypic stages, green and red-violet. The green phenotypic stage (P1) corresponds to samples collected in the spring (March) where the weather is characterized by moderate temperature $\left(26^{\circ} \mathrm{C}\right)$ and humidity $(61 \%)$. Meanwhile, the red-violet phenotypic stage (P2) corresponds to the samples collected in summer (the end of August) where the temperature (between $40{ }^{\circ} \mathrm{C}$ and $46^{\circ} \mathrm{C}$ ) is high with a long exposition to ultra- violet radiation ( $13 \mathrm{~h}$ and $31 \mathrm{~min}$ ) (Samson, 2017).

Halophytes can be classified/distinguished based on their succulence, which is identified as water amount per unit of leaf area (Flowers, 1985; Ghazanfar et al., 2014). The main factor responsible for the adaptation of halophytes to growth in extreme conditions is the hydration maintenance. In this way, Arthroncnemum, Halocnemum, and Suaeda are considered as succulent species (Atia et al., 2014; Ksouri et al., 2012), having succulent or fleshy aerial parts as a way of protection. Therefore, the studied samples revealed high moisture content: 80.1 and $79.3 \mathrm{~g} / 100 \mathrm{~g}$ fw for AP1 and AP2, 77.4 and $76.0 \mathrm{~g} /$ $100 \mathrm{~g}$ fw for HP1 and HP2, and 74.4 and $73.2 \mathrm{~g} / 100 \mathrm{~g}$ fw for SP1 and SP2, respectively.

Tissues that possess succulence are created by the hypertrophy of some parenchymal cells and are usually used as a water reserve tissues. Parenchyma tissues are constituted by cells that have a thin pecto-cellulosic wall with plasmodesma channels in order to allow cellular interchange and symplastic circulation. The ionic compartmentalization in vacuoles is also important for the intracellular management of salts tolerance (Slama et al., 2015). Moreover, the accumulation of some cations like $\mathrm{K}^{+}$is another strategy to replace the high $\mathrm{Na}^{+}$concentration (Flowers et al., 2010).

It is very well known that halophytes are rich in ashes (Barreira et al., 2017; Borah et al., 2009), whose content is highly correlated with the ecophysiological aspects of halophyte species, mainly the soil concentration in salts. In terms of ecology, there are two types of halophytes according to their salt tolerance degree (i) facultative halophytes, which can survive normally in soils contaminated or not by high salt concentration thanks of their resistance strategies (ex. Atriplex), (ii) obligate halophytes or Euhalophytes, which are only able to develop in soils with high salinity concentrations (ex. Halocnemum strobilaceum (Biondi et al., 2013); Arthrocnemum indicum (Willd).Moq (Rodrigues et al., 2014); Sueada fruticosa (Hameed et al., 2012)).

Although, the three selected species are consider as obligated halophytes, it tolerance of salt is much different. If we organized the three species as their tolerance in salt according to the salt gradient in Nature (in the studied salt marshes). Halocnemum strobilaceum naturally growth in the middle of the salt marshes (particularly in the first line of the Sebkha, Monastir) where salinity can reach $300 \mathrm{mM}$ of $\mathrm{NaCl}$ (Hameed et al., 2012). Arthrocnemum indicum is also an obligate halophyte but able to resist less soil salt concentrations than Halocnemum strobilaceum. And were collected in the second line of Sebkha plants. Wherease, Sueada fruticosa is located far from the middle of the Sebkha in the third line of Sebkha species.

Naturally the soil salt gradient is different in the Sebkha area and this approach of stages is applicable for green samples. During summer, when samples reach the maturity, drought and excessive temperature increase soil salt accumulation mainly in the middle of the Sebkha, which is completely dried. 
H. strobilaceum presents the higher levels of ashes in both phenotypical stages $(6.4$ and $7.4 \mathrm{~g} / 100 \mathrm{~g} \mathrm{fw}$ in green and red-violet shoots, respectively). Actually, it is an obligate halophyte that needs high salt concentrations to survive. This species is usually developed in hypersaline salt marshes, where salinity levels are usually higher than seawater (Gairola et al., 2015).

As previously mentioned, $A$. indicum and $S$. fruticosa are also considered as obligate halophytes, however, these species tolerate lower salinity concentrations than $H$. strobilaceum, with an optimum of $300 \mathrm{mM} \mathrm{NaCl}$ (Hameed et al., 2012). For this reason, in both phenotypes (green and red-violet), the ashes content of these two species ( $A$. indicum and $S$. fruticosa) was significantly lower $(\mathrm{p}<0.05)$ comparing with $H$. strobilaceum shoots. Particularly, A. indicum presented 3.0 and $3.4 \mathrm{~g}$ of ashes per $100 \mathrm{~g}$ fw in green and red-violet shoots, respectively, and $S$. fruticosa ashes content ranged from 2.7 to $2.5 \mathrm{~g} / 100 \mathrm{~g}$ fw, in green and red-violet shoots, respectively. It is known that $S$. fruticosa adopts a strategy of controlling high concentrations of intracellular $\mathrm{Na}^{+}$ by the cuticle diffusion or stomat aguttation. This mechanism is important because the long absorption of high salt amounts is highly correlated with the ionic imbalance in plant cells (Hameed et al., 2012).

Table 1 shows micro and macroelements content of the analysed wild Tunisian halophytes, which as expected, stand out by their high sodium content. This macroelement was the most abundant mineral in all analysed samples (with the exception of red-violet shoots of $S$. fruticosa), followed by $\mathrm{Ca}, \mathrm{Mg}$ and $\mathrm{K}$. This tendency was previously reported by Rocha et al. (2017), in leaves of Carpobrotus edulis L., an edible succulent halophyte plant native to the coast of South Africa. Moreover, $\mathrm{Zn}$ was generally the main microelement and its content was between $0.17 \mathrm{mg} / 100 \mathrm{~g}$ in AP2 and $0.76 \mathrm{mg} / 100 \mathrm{~g}$ in HP2, while Mn was found in lower amounts. As previously reported, halophytes stand out due to their content of $\mathrm{Na}$, which ranged from $84.63-518.62 \mathrm{mg}$ / $100 \mathrm{~g}$ in SP1 and HP2, respectively. These values are in accordance with those found in other different halophytes as Carpobrotus edulis L. (around $300 \mathrm{mg}$ of Na per $100 \mathrm{~g}$ of leaves) (Rocha et al., 2017), Thespesia populnea (around $500 \mathrm{mg}$ of $\mathrm{Na}$ per $100 \mathrm{~g}$ of leaves) (Rangani et al., 2019), and Crithmum maritimum (290 mg of $\mathrm{Na}$ per $100 \mathrm{~g}$ of leaves) (Guil Guerrero et al., 1998).

It is reported that under osmotic imbalance, plants accumulate osmolytes for osmotic adjustments. These compounds are highly soluble, such as proline or sugars, and interfere with normal metabolic reactions given their non-toxicity even at high concentrations (Slama et al., 2015). The influence of phenotypical state in the mineral content was different depending on the particular element and the studied species. Generally, the content of $\mathrm{Mg}, \mathrm{Ca}, \mathrm{Na}, \mathrm{Fe}$, and $\mathrm{Mn}$ was higher in redviolet shoots comparing with their respective green shoots. However, the content of K was generally higher in green shoots. Sun et al. (2012) evaluated the change caused by maturity on chemical composition of Suaeda glauca in order to determinate the suitable harvest date according to the nutritional characteristics of this halophyte plant. These authors found significant differences, correlated with the date of harvest, in ashes, $\mathrm{Na}, \mathrm{Ca}, \mathrm{Fe}, \mathrm{Cu}$, and $\mathrm{Zn}$ content. In this sense, they observed that Na content was significantly decreased with maturity (as occur in samples of $A$. indicum analysed in the present study), while the level of other minerals, such as $\mathrm{K}$ and $\mathrm{Mg}$, were not significantly modified. On the other hand, in the case of $H$. strobilaceum, HP2 showed a significant higher content $(\mathrm{p}<0.05)$ of $\mathrm{Na}$ than HP1. It could be explained because this specie is classified as an obligate halophyte, which grows in salt marshes characterized by a high concentration of $\mathrm{NaCl}$. This concentration greatly increases in the summer period as the soil salt accumulation rises as a consequence of the high temperatures and the low rainfall. The increase of Na concentration could be also related with higher content of $\mathrm{Ca}$ (as observed in HP2 compared to HP1). It could be a plant physiologically defence mechanism, which contribute to re-establish the homeostatic conditions in the presence of an excess of $\mathrm{Na}^{+}$and provide an inward net flux of water, allowing turgor maintenance at the cell level. Moreover, this approach could allow to maintain a low $\mathrm{Ca}^{2+}$ activity in the cytosol due to the interactions between $\mathrm{Na}^{+}$and $\mathrm{Ca}^{2+}$ under salt stress (Tipirdamaz et al., 2006).

Total available carbohydrates (TAC) were analysed in all species, in both seasonal/phenotypic stages, as shown in Table 1 . Our results showed that SP1 revealed the higher TAC content $(4.1 \mathrm{~g} / 100 \mathrm{~g}$ fw) but this amount lightly decreases in SP2 $(3.7 \mathrm{~g} / 100 \mathrm{~g} \mathrm{fw})$, however this reduction was no significant. AP1 and HP1 presented similar TAC amounts (2.4 and $2.6 \mathrm{~g} / 100 \mathrm{~g} \mathrm{fw})$ and this content increased in the same way in AP2 and HP2 (3.2 and $3.1 \mathrm{~g} / 100 \mathrm{~g} \mathrm{fw}$, respectively). These results are correlated with those reported by Doddema et al. (1986) in A. fruticosum roots from Jordan. These authors studied the effect of seasonal changes of soil salinity on the metabolism of this species.

Regarding their role in salt tolerance mechanism, cellular carbohydrates contribute for the osmotic adjustment (Slama et al., 2015), when available in high concentrations. Thus, the accumulation of soluble carbohydrates as a response to salt stress depends on the species because of the widely variability observed in halophytic species.

The higher values of proteins content (Table 1) were found in SP1 with values of $4.4 \mathrm{~g} / 100 \mathrm{~g}$ fw. However, this amount was significantly lower $(\mathrm{p}<0.05)$ in SP2 $(2.5 \mathrm{~g} / 100 \mathrm{~g} \mathrm{fw})$. The same tendency was observed in the other two species, being protein content 3.3 and $3.0 \mathrm{~g} /$ $100 \mathrm{~g} \mathrm{fw}$ in HP1 and HP2, respectively, while AP1 and AP2 presented $3.1 \mathrm{~g} / 100 \mathrm{~g}$ fw and $2.5 \mathrm{~g} / 100 \mathrm{~g}$ fw. In general, red-violet shoots (whose phenotype changes from green colour due to salinity stress) present lower protein content. This can be explained according to Win and Oo (2017), who reported that salinity causes a decrease or increase in total protein content and in some cases several proteins fade out (Yildiz, 2007). For example, under salt treatment, shoots of the halophyte Bruguiera parviflora (Roxb.) Wight \& Arn. ex Griff. show a decrease of total proteins (Parida et al., 2002). Moreover, the lower protein contain in red-violet shoots may be due to the fact that the salinity stress could cause toxic cytosolic concentrations of $\mathrm{Na}$, hindering the protein synthesis (Tipirdamaz et al., 2006). Similar protein content was reported by (Barreira et al., 2017) in A. macrostachyum green shoots, higher than other halophytes such as Sarcocornia perennis subsp. perennis, S. perennis subsp. Alpini, and Salicornia ramosissima.

Halophytes are also a good source of dietary fiber (Díaz et al., 2013), especially some Chenopodiaceae species such as Salicornia genus (Barreira et al., 2017). In this context, and according to European Regulation (EC) No 1924/2006 (European Parliament \& Council of the European Union, 2006), the claim "source of dietary fiber" and "high dietary fiber" may be used for these wild halophytes as their content in total dietary fiber (TDF) is higher than 3 and $6 \mathrm{~g} / 100 \mathrm{~g} \mathrm{fw}$, respectively. Particularly, S. fruticosa (SP1 and SP2) shoots contain higher total dietary fiber amounts $(10.1 \mathrm{~g} / 100 \mathrm{~g}$ fw and $12.0 \mathrm{~g} / 100 \mathrm{~g}$ fw, respectively) comparing with the other analysed species. In the case of $H$. strobilaceum and $S$. fruticosa, the content of TDF was significantly higher $(\mathrm{p}<0.05)$ in red-violet shoots compared to green shoots. In this sense, it is reported that the content of dietary fiber in vegetables increases as consequence of maturity process (Punna \& Paruchuri, 2004).

Comparing to previous research of Barreira et al. (2017), green shoots of the studied samples present higher total dietary fiber contents than those found in green shoots of Sarcocornia perennis subsp. perennis, S. perennis subsp. Alpini, Salicornia ramosissima, and A. macrostachyum from South Portugal.

Dietary fiber plays an important role in preventing gastrointestinal disorders such as chronic constipation or some types of colitis, prevents cardiovascular diseases and reduce the risk of developing colon cancer (Fuller et al. 2016), and controls cholesterol blood levels and glycemia (Hounsome \& Hounsome, 2011). Hence, the estimation of the amount of soluble and insoluble fractions is crucial for the evaluation of food quality and the identification of "functional foods" (Rodríguez et al., 2006). The recommended dietary fiber intake is $25 \mathrm{~g} /$ day in adults (EFSA, 2010). Therefore, an edible portion $(100 \mathrm{~g})$ of this wild shoots could cover $29-48 \%$ of the daily dietary intake of this nutrient $(H$. 
strobilaceum and $S$. fruticosa, respectively). Food industry is looking for new sources of dietary fiber (Chau \& Huang, 2003) and, in this sense, the study of halophyte plants that could be consider as functional ingredients constitutes a great research field.

Moreover, Siddiq (2018) suggested that the appropriate ratio of dietary fiber fractions is 30:70 for soluble and insoluble fraction, respectively. For the analysed halophytes, the insoluble dietary fiber fraction was the prevalent one (Table 1), representing about $68.64 \%$ and $74.86 \%$ of total dietary fiber for AP1 and AP2, respectively; 80.60 $\%$ and $87.67 \%$ for HP1 and HP2, respectively, and $67 \%$ and $63.36 \%$ for SP1 and SP2, respectively.

Regarding fat content, $S$. fruticosa shoots revealed the highest content in this macronutrient; with values of 4.9 and $6.0 \mathrm{~g} / 100 \mathrm{~g} \mathrm{fw}$ in SP1 and SP2 shoots, respectively (Table 1 ). These results showed that fat content was significantly higher $(\mathrm{p}<0.05)$ in stressed shoots (redviolet maturity stage). In this sense, it is reported that some halophytic species show an increase of FA amount when they are under saltstress conditions. This could be a strategy to increase the salt tolerance by modification of salt membrane permeability (Glenn et al., 1999).

$S$. fruticos $a$ and $H$. strobilaceum presented a different tendency, total fat amount in $H$. strobilaceum seems to be highly affected by the high salt concentration of soil, indeed, total levels decrease significantly in red-violet shoots (HP2, $2.4 \mathrm{~g} / 100 \mathrm{~g} \mathrm{fw}$ ) comparing to green shoots (HP1, $3.33 \mathrm{~g} / 100 \mathrm{~g} \mathrm{fw}$ ), while $S$. fruticosa (which is a less salt tolerant halophyte comparing with the other two species) significantly $(\mathrm{p}<0.05)$ increase it content in red-violet shoots $(6.0 \mathrm{~g} / 100 \mathrm{~g} \mathrm{fw})$ as physiological strategy to decrease salt membranes permeability in order to tolerate the soil salinity increase during summer in the harvested area. On the other hand, for $A$. indicum no significant differences $(\mathrm{p}<0.05)$ were observed in fat content between different maturity (phenotype) stages. This species showed values for fat content of $2.6 \mathrm{~g} /$ $100 \mathrm{~g} \mathrm{fw}$, in green (AP1) and red-violet (AP2) shoots, respectively.

Regarding the analysis of fatty acids profile, up to twenty FA were detected in most of the samples. In Table 2, a full FA characterization of the three halophytes was reported, as well as total SFA, MUFA, PUFA, the ratios PUFA/SFA, n- $6 / n-3$ ratio, and lipid quality index.

In general, in the studied samples it is observed an important predominance of PUFA, being higher the Omega-3 (PUFA n-3) in green shoots, while in red-violet shoots a higher percentage of Omega- 6 (PUFA n-6), such as linoleic acid (LA) was observed.

LA was the main PUFA in all analysed halophytes, as follows: SP2 > AP2 > HP1 > SP1 > HP2 > AP1; while $\alpha$-linolenic acid (ALA) was only characterized in $H$. strobilaceum wild shoots, being higher in the green phenotypic stage (HP1 > HP2). Barreira et al. (2017) reported $47.0 \%$ of PUFA in A. macrostachyum green shoots from Algarve (Portugal), with high abundance of $\alpha$-linolenic acid C18:3n-3 (25.9\%).

Other relevant fraction was the SFA, being palmitic acid (C16:0) the major fatty acid in all analysed samples, being much higher in the green phenotypic stage comparing with the red-violet one (SP1 > AP1 > HP1 > HP2 > AP2 > SP2). Other important SFA found in the analysed halophytes were stearic acid, behenic acid, and lignoceric acid. In all cases, SP2 sample presents the lower amount of SFA, while SP1 and HP2 highlighted due to their content in palmitic and stearic acids (in the case of SP1) and behenic and lignoceric acids (in the case of HP2). Finally, regarding MUFA content, oleic acid (C18:1n-9) was the most abundant fatty acid, as follows: $\mathrm{SP} 1>\mathrm{AP} 1>\mathrm{HP} 2>\mathrm{AP} 2>\mathrm{HP} 1>\mathrm{SP} 2$.

In halophyte plants, the SFA level is highly influenced by environmental conditions (Duarte et al., 2018). Hence, its content may be decreased or increased to improve the membrane barrier capacity, to control their permeability and to contribute in the selectivity of cellular interchange and symplastic circulation (Duarte et al., 2018; Rozentsvet et al., 2012). Nonetheless, decreasing unsaturated FA and reducing unsaturated/saturated fatty acid ratio, affect the membrane permeability (Slama et al., 2007) and therefore the selective ions absorption
(Wang et al., 2007).

In other cases, some species increase unsaturation of membrane as a strategy to enhance salt tolerance (Chen et al., 2018), to reduce sodium ratios (Zhang et al., 2010) and to protect photosystem II (Sui et al. 2010). Hence, our results confirm that regardless of the environmental influence, the studied samples contain a good fatty acids profile.

Due to their high PUFA content, different authors reported halophytes as commercial green oil for human consumption due to their good quality, equivalent to conventional oil seed (Khan \& Qaiser, 2006; Qasim et al., 2011; Weber et al., 2007).

In order to revalorize and point out the nutritional relevance of this halophytes consumption, the analysed samples will be compared with other conventional vegetables. In this sense, it can be observed that the proteins content of the studied shoots is similar to the one reported for spinach (Spinacia oleracea L., $3.63 \mathrm{~g} / 100 \mathrm{~g} \mathrm{fw}$ ), brussels sprouts (Brassica oleracea L. var. gemmifera, $3.38 \mathrm{~g} / 100 \mathrm{~g}$, fw) and sprouting broccoli (Brassica oleracea L. var. italica, $2.82 \mathrm{~g} / 100 \mathrm{~g}$, fw) (USDA, 2016). Our results, and particularly the dietary fiber content of $H$. strobilaceum, was similar or even higher than those reported to eggplant (Solanum melongena, 6.6 g/100 g), artichoke (Cynara cardunculus, $5.5 \mathrm{~g}$ / $100 \mathrm{~g}$ ), beetroot (Beta vulgaris maritime, $2.8 \mathrm{~g} / 100 \mathrm{~g}$ ), and spinach (Spinacia oleacera, 2.2 g/100 g) (Hounsome \& Hounsome, 2011; USDA, 2016).

Interestingly, the studied samples are widely rich in total fats (between 2.4-12.03 /100 g, fw) comparing with some conventional vegetables that contain lower amounts, such as spinach (Spinacia oleracea L., $0.39 \mathrm{~g} / 100 \mathrm{~g} \mathrm{fw}$ ), sprouting broccoli (Brassica oleracea L. var. italica, $0.37 \mathrm{~g} / 100 \mathrm{~g} \mathrm{fw}$ ), brussels sprouts (Brassica oleracea L. var. gemmifera, $0.30 \mathrm{~g} / 100 \mathrm{~g} \mathrm{fw}$ ), and beetroot (Beta vulgaris maritima, $0.17 \mathrm{~g} / 100 \mathrm{~g} \mathrm{fw}$ ) (USDA, 2016).

Furthermore, Arthrocnemum, Halocnemum and Suaeda shoots present an interesting fatty acids profile. Hence, they seem to be important sources of MUFA and SFA comparing with conventional vegetables (USDA, 2016).

\subsection{Indexes of lipid quality}

The consumption of MUFA and PUFA is known for being good in controlling plasma cholesterol levels (Fernandez \& West, 2005) and preventing several diseases like cardiovascular disorder, diabetes type 2, and cancer (Wanders et al., 2017). Omega-3 and Omega-6 (FA) are known for their beneficial health effects by preventing cardiovascular disease, blood pressure, decreasing triglycerides levels, preserving arteries smooth, reducing diabetes risks, and fortifying brain functions and cells growth (Hounsome \& Hounsome, 2011).

Taking account of the role of PUFA in cardiovascular diseases, indexes of atherogenicity (IA) and thrombogenicity (IT) are usually investigated to analyse and foretell the health risks degree or benefits of this plant consumption (Barreira et al., 2017). Whereas SFA play a proatherogenic role as they promote FA adherence in cells, unsaturated FA decrease phospholipids, cholesterol, and esterified FA in blood as well as prevent plaque gathering and coronary diseases. Our results revealed that Suaeda and Arthrocnemum red-violet shoots revealed lowest IT (0.03 and 0.07) and IA (0.09 and 0.15). Moreover, Halocnemum green shoots (HP1) registered lower IT and IA $(0.22$ and 0.42), comparing with Suaeda green shoots (SP1; 0.29 and 0.46). Indexes of atherogenicity (IA) and thrombogenicity (IT) were highly correlated with PUFA and SFA content, as well as PUFA/SFA ratio. Taking into account the PUFA/SFA ratio results, it's important to highlight the significant differences observed between different phenotypic stages of some of the analysed species, as in the case of Sueda shoots. In this case Sueda green shoots (SP1) present a much lower PUFA/SFA ratio (1.6) than the red-violet sample (SP2), which present a ratio of 7.9. Suaeda fruticosa is an obligate halophyte which is the less tolerant to salt of the three studies species. Among them, as mentioned in the text, this specie is able to modify its composition in SFA and 
Table 2

Fatty acids profile (relative percentage, \%) in Tunisian halophyte species in two different phenotipic stages.

\begin{tabular}{|c|c|c|c|c|c|c|c|}
\hline \multirow{2}{*}{\multicolumn{2}{|c|}{ Fatty Acid (relative percentage, \%) }} & \multicolumn{2}{|c|}{ Arthrocnemum indicum } & \multicolumn{2}{|c|}{ Halocnemum strobilaceum } & \multicolumn{2}{|l|}{ Suaeda fruticosa } \\
\hline & & \multirow{2}{*}{$\begin{array}{l}\text { Green } \\
\text { AP1 } \\
\text { nd }\end{array}$} & \multirow{2}{*}{$\begin{array}{l}\text { Red-violet } \\
\text { AP2 } \\
\text { nd }\end{array}$} & \multirow{2}{*}{$\begin{array}{l}\text { Green } \\
\text { HP1 } \\
\text { nd }\end{array}$} & \multirow{2}{*}{$\begin{array}{l}\text { Red-violet } \\
\text { HP2 } \\
\text { nd }\end{array}$} & \multirow{2}{*}{$\begin{array}{l}\text { Green } \\
\text { SP1 } \\
0.57 \pm 0.03\end{array}$} & \multirow{2}{*}{$\begin{array}{l}\text { Red-violet } \\
\text { SP2 } \\
0.09 \pm 0.01\end{array}$} \\
\hline Caproic acid & $\mathrm{C} 6: 0$ & & & & & & \\
\hline Caprylic acid & C8:0 & nd & nd & nd & nd & $0.22 \pm 0.01$ & $0.01 \pm 0.01$ \\
\hline Capric acid & $\mathrm{C} 10: 0$ & $0.38 \pm 0.05$ & $0.06 \pm 0.00$ & $0.08 \pm 0.01$ & $0.25 \pm 0.03$ & $0.41 \pm 0.01$ & $0.05 \pm 0.00$ \\
\hline Undecanoic acid & C11:0 & nd & nd & nd & nd & $0.11 \pm 0.00$ & $0.14 \pm 0.00$ \\
\hline Lauric acid & C12:0 & $0.55 \pm 0.03$ & $0.05 \pm 0.00$ & $0.59 \pm 0.02$ & $1.07 \pm 0.00$ & $0.66 \pm 0.01$ & $0.09 \pm 0.01$ \\
\hline Tridecanoic acid & C13:0 & nd & $0.08 \pm 0.00$ & nd & nd & $0.06 \pm 0.00$ & nd \\
\hline Myristic acid & C14:0 & $2.20 \pm 0.10$ & $0.31 \pm 0.01$ & $0.75 \pm 0.01$ & $1.56 \pm 0.02$ & $2.36 \pm 0.07$ & $0.26 \pm 0.01$ \\
\hline Myristoleicacid & C14:1 & nd & nd & nd & nd & $0.11 \pm 0.02$ & $0.01 \pm 0.00$ \\
\hline Pentadecanoic acid & C15:0 & $0.30 \pm 0.03$ & $0.07 \pm 0.00$ & $0.17 \pm 0.00$ & $0.22 \pm 0.01$ & $0.32 \pm 0.02$ & $0.04 \pm 0.00$ \\
\hline Palmitic acid & C16:0 & $17.9 \pm 0.2$ & $11.39 \pm 0.08$ & $15.32 \pm 0.08$ & $15.5 \pm 0.1$ & $19.3 \pm 0.1$ & $6.52 \pm 0.07$ \\
\hline Palmitoleic acid & C16:1 & $0.13 \pm 0.00$ & $0.03 \pm 0.00$ & $0.11 \pm 0.01$ & $0.24 \pm 0.00$ & $0.12 \pm 0.00$ & $0.14 \pm 0.01$ \\
\hline Heptadecanoic acid & $\mathrm{C} 17: 0$ & $0.25 \pm 0.03$ & $0.13 \pm 0.00$ & $0.22 \pm 0.01$ & $0.36 \pm 0.01$ & $0.26 \pm 0.01$ & $0.07 \pm 0.00$ \\
\hline Cis-10-heptadecanoic & $\mathrm{C} 17: 1$ & nd & nd & nd & nd & nd & $0.04 \pm 0.00$ \\
\hline Stearic acid & $\mathrm{C} 18: 0$ & $5.75 \pm 0.06$ & $2.42 \pm 0.02$ & $2.087 \pm 0.006$ & $4.12 \pm 0.02$ & $6.94 \pm 0.04$ & $1.41 \pm 0.06$ \\
\hline Oleic acid & $\mathrm{C} 18: 1 \mathrm{n} 9 \mathrm{c}$ & $5.4 \pm 0.1$ & $13.04 \pm 0.02$ & $7.30 \pm 0.02$ & $4.938 \pm 0.002$ & $7.2 \pm 0.2$ & $6.559 \pm 0.004$ \\
\hline Linolelaidic acid & $\mathrm{C} 18: 2 \mathrm{n} 6 \mathrm{t}$ & $0.19 \pm 0.01$ & $0.12 \pm 0.00$ & $0.16 \pm 0.01$ & $0.29 \pm 0.01$ & $0.25 \pm 0.00$ & nd \\
\hline Linoleic acid (LA) & $\mathrm{C} 18 \mathrm{a} 2 \mathrm{n} 6 \mathrm{c}$ & $20.70 \pm 0.20$ & $63.50 \pm 0.10$ & $30.60 \pm 0.10$ & $25.20 \pm 0.20$ & $26.60 \pm 0.20$ & $75.22 \pm 0.03$ \\
\hline Stearic acid & C18:3n3 & $40.50 \pm 0.50$ & $5.92 \pm 0.03$ & nd & nd & $29.20 \pm 0.40$ & $7.40 \pm 0.02$ \\
\hline$\delta$-linolenic acid & C18:3n6 & nd & nd & $0.24 \pm 0.02$ & $0.28 \pm 0.04$ & nd & nd \\
\hline$\alpha$-linolenicacid (ALA) & C18:3n3 & nd & nd & $33.30 \pm 0.10$ & $22.03 \pm 0.03$ & nd & nd \\
\hline Arachidic acid & C20:0 & $0.63 \pm 0.00$ & $0.63 \pm 0.01$ & $2.50 \pm 0.03$ & $10.90 \pm 0.10$ & $1.00 \pm 0.04$ & $0.58 \pm 0.00$ \\
\hline Cis-11-eicosenoic acid & $\mathrm{C} 20: 1$ & nd & $0.20 \pm 0.01$ & $0.10 \pm 0.00$ & $0.05 \pm 0.00$ & $0.09 \pm 0.01$ & $0.12 \pm 0.01$ \\
\hline Cis-11.14 eicosenoic acid & $\mathrm{C} 20: 2$ & nd & nd & $0.24 \pm 0.00$ & $0.13 \pm 0.04$ & nd & nd \\
\hline Heneicosylic acid & $\mathrm{C} 21: 0$ & $0.15 \pm 0.01$ & $0.05 \pm 0.00$ & $0.22 \pm 0.00$ & $0.42 \pm 0.04$ & $0.18 \pm 0.02$ & $0.06 \pm 0.01$ \\
\hline Dihomo- $\alpha$-linolenic acid & C20:3n6 & nd & nd & $0.15 \pm 0.01$ & $0.35 \pm 0.01$ & nd & nd \\
\hline Arachidonic acid & C20:4n 6 & nd & $0.20 \pm 0.03$ & $0.13 \pm 0.00$ & $0.28 \pm 0.03$ & nd & $0.04 \pm 0.01$ \\
\hline Eicosatrienoic acid & $\mathrm{C} 20: 3 \mathrm{n} 3$ & nd & nd & $0.0735 \pm 0.0007$ & $0.106 \pm 0.001$ & nd & nd \\
\hline Behenic acid & $\mathrm{C} 22: 0$ & $1.62 \pm 0.04$ & $0.66 \pm 0.05$ & $3.52 \pm 0.01$ & $6.01 \pm 0.08$ & $1.87 \pm 0.03$ & $0.62 \pm 0.01$ \\
\hline Eicospentanoic acid & $\mathrm{C} 20: 5 \mathrm{n} 3$ & nd & nd & nd & nd & $0.65 \pm 0.01$ & $0.048 \pm 0.003$ \\
\hline Tricosanoic acid & $\mathrm{C} 23: 0$ & nd & nd & nd & nd & nd & nd \\
\hline Lignoceric acid & $\mathrm{C} 24: 0$ & $3.40 \pm 0.30$ & $1.18 \pm 0.06$ & $2.20 \pm 0.20$ & $5.60 \pm 0.30$ & $1.55 \pm 0.03$ & $0.49 \pm 0.00$ \\
\hline SFA & & $33.1 \pm 0.8^{\mathrm{d}, \mathrm{B}}$ & $17.0 \pm 0.1^{\mathrm{e}, \mathrm{A}}$ & $27.6 \pm 0.3^{\mathrm{c}, \mathrm{A}}$ & $46.1 \pm 0.2^{\mathrm{a}, \mathrm{B}}$ & $35.8 \pm 0.4^{\mathrm{b}, \mathrm{B}}$ & $10.5 \pm 0.02^{\mathrm{f}, \mathrm{A}}$ \\
\hline MUFA & & $5.5 \pm 0.1^{\mathrm{e}, \mathrm{A}}$ & $13.3 \pm 0.0^{\mathrm{a}, \mathrm{B}}$ & $7.5 \pm 0.0^{\mathrm{b}, \mathrm{B}}$ & $5.2 \pm 0.0^{\mathrm{f}, \mathrm{A}}$ & $7.6 \pm 0.3^{\mathrm{c}, \mathrm{B}}$ & $6.9 \pm 0.0^{\mathrm{d}, \mathrm{A}}$ \\
\hline PUFA & & $61.4 \pm 0.7^{\mathrm{d}, \mathrm{A}}$ & $69.7 \pm 0.1^{\mathrm{b}, \mathrm{B}}$ & $64.9 \pm 0.3^{\mathrm{c}, \mathrm{B}}$ & $48.7 \pm 0.2^{\mathrm{f}, \mathrm{A}}$ & $56.6 \pm 0.7^{\mathrm{e}, \mathrm{A}}$ & $82.7 \pm 0.0^{\mathrm{a}, \mathrm{B}}$ \\
\hline PUFA/SFA & & 1.9 & 4.1 & 2.4 & 1.1 & 1.6 & 7.9 \\
\hline$\Sigma(\mathrm{n}-3)$ & & 40.5 & 5.2 & 33.4 & 22.1 & 29.9 & 7.4 \\
\hline$\Sigma(\mathrm{n}-6)$ & & 20.9 & 63.8 & 31.3 & 26.4 & 26.9 & 75.3 \\
\hline$\Sigma(\mathrm{n}-3) / \Sigma(\mathrm{n}-6)$ & & 1.9 & 0.1 & 1.1 & 0.8 & 1.1 & 0.1 \\
\hline PUFA-n3 & & 20.9 & 64.5 & 31.5 & 26.6 & 26.8 & 75.3 \\
\hline PUFA-n6 & & 40.5 & 5.9 & 33.6 & 22.3 & 29.8 & 7.5 \\
\hline IA (Index of atherogenicity) & & 0.41 & 0.15 & 0.26 & 0.42 & 0.46 & 0.09 \\
\hline TI (Index of thrombogenicity) & & 0.30 & 0.07 & 0.16 & 0.22 & 0.29 & 0.03 \\
\hline
\end{tabular}

Results are presented as mean \pm SD. nd: not detected. In each row, different letters means significant differences $(\mathrm{p}<0.05)$ between samples. Small superscript letter means differences between all samples analysed, whereas capital superscript letter means difference between different phenotypic stages (P1 and P2) for the same species.

PUFA to limit the permeability of its membranes to $\mathrm{Na}$, therefore, the red-violet phenotypic stage present a much higher relative percentage of PUFA and lower SFA comparing with the green phenotypic stage, in summer period (when red-violet samples were collected) it is very common that mineral concentration and salinity of the sediment was much higher due to the high temperatures and the lower rainfall, than in spring. Being the PUFA/SFA ratio much higher in red-violet phenotypic stage.

\subsection{Vitamins content}

Vitamin C (ascorbic acid) and E (tocopherols) values in the studied halophyte plants are shown in Table 3. Ascorbic acid is one of the most essential metabolite for plants which acts as a cofactor for photosynthetic enzymes and enzymes involved in biosynthesis of phytohormones, anthocyanins, and the antioxidants regeneration. Plants exposed to drought and salinity, such as the analysed halophytes, has increased ascorbic acid content (Ahanger et al., 2017) in order to develop an adaptive strategy to stress caused by salinity conditions and water deficit (Najjaa et al., 2018).
Ascorbic acid content was found in all analysed samples (AP2 > AP1 > HP2 > HP1 > SP1 > SP2) and ranged from $2.46 \mathrm{mg} /$ $100 \mathrm{~g} \mathrm{fw}$ (SP2) to $19.17 \mathrm{mg} / 100 \mathrm{~g}$ fw (AP2). Rangani et al. (2019) evaluated the nutritional characteristics and phytochemical composition of the Thespesia populnea (L.) Sol. ex Corrêa leaves and reported values of ascorbic acid of $9.4 \mathrm{mg} / 100 \mathrm{~g} \mathrm{fw}$, being this content similar to that found in H. Strobilaceum. In this halophyte, as well as in A. indicum, no significant differences of ascorbic acid content were found between different maturity stages, however, in the case of $S$. fruticosa, the amount of ascorbic acid was significantly higher $(\mathrm{p}<0.05)$ in green shoots compared to red-violet shoots.

In the present study, four different vitamin $\mathrm{E}$ isomers were analysed, namely $\alpha$-tocopherol, $\beta$-tocopherol, $\delta$-tocopherol, and $\gamma$-tocopherol, being $\alpha$-tocopherol the major isomer in all analysed samples. Total tocopherols were quantified in the analysed halophytes (HP1 > SP2 > HP2 > SP1 > AP1 > AP2). Therefore, the highest total tocopherols content was detected in HP1 (15.39 mg/100 gfw), followed by SP2 $(13.66 \mathrm{mg} / 100 \mathrm{~g} \mathrm{fw})$, while the lowest contents were found inAP1 and AP2, which revealed 2.32and $2.71 \mathrm{mg} / 100 \mathrm{~g}$ fw, respectively. 
Table 3

Vitamins C (ascorbic acid) and E (tocopherols) content (mg/100 g fw) in Tunisian halophyte species in two different phenotipic stages.

\begin{tabular}{|c|c|c|c|c|c|c|c|c|}
\hline Halophytes & Phenotypic stage & Code & Ascorbic acid (mg/100 g) & $\alpha$-tocopherol & $\beta$-tocopherol & $\delta$-tocopherol & $\gamma$-tocopherol & Total Tocopherols \\
\hline \multirow{2}{*}{ Arthrocnemum indicum } & Green & AP1 & $18.34 \pm 0.19^{\mathrm{d}, \mathrm{A}}$ & $1.95 \pm 0.02^{\mathrm{a}, \mathrm{A}}$ & $0.36 \pm 0.01^{\mathrm{e}, \mathrm{B}}$ & $0.03 \pm 0.00^{\mathrm{a}, \mathrm{A}}$ & $0.36 \pm 0.01^{\mathrm{b}}$ & $2.71 \pm 0.00^{\mathrm{b}, \mathrm{B}}$ \\
\hline & Red-Violet & AP2 & $19.17 \pm 0.50^{\mathrm{d}, \mathrm{A}}$ & $2.12 \pm 0.01^{\mathrm{a}, \mathrm{B}}$ & $0.06 \pm 0.00^{\mathrm{c}, \mathrm{A}}$ & $0.14 \pm 0.00^{\mathrm{c}, \mathrm{B}}$ & nd & $2.32 \pm 0.01^{\mathrm{a}, \mathrm{A}}$ \\
\hline \multirow[b]{2}{*}{ Halocnemum strobilaceum } & Green & HP1 & $7.38 \pm 0.54^{\mathrm{c}, \mathrm{A}}$ & $3.35 \pm 0.08^{\mathrm{c}, \mathrm{A}}$ & $0.24 \pm 0.01^{\mathrm{d}, \mathrm{A}}$ & $8.59 \pm 0.22^{\mathrm{f}, \mathrm{B}}$ & $3.24 \pm 0.05^{\mathrm{d}, \mathrm{B}}$ & $15.39 \pm 0.27^{\mathrm{f}, \mathrm{B}}$ \\
\hline & Red-Violet & HP2 & $6.61 \pm 0.27^{\mathrm{c}, \mathrm{A}}$ & $3.71 \pm 0.06^{\mathrm{c}, \mathrm{A}}$ & $1.22 \pm 0.00^{\mathrm{f}, \mathrm{B}}$ & $3.71 \pm 1.71^{\mathrm{e}, \mathrm{A}}$ & $1.02 \pm 0.00^{\mathrm{c}, \mathrm{A}}$ & $9.66 \pm 1.74^{\mathrm{d}, \mathrm{A}}$ \\
\hline \multirow{2}{*}{ Suaeda fruticosa } & Green & SP1 & $4.14 \pm 0.57^{\mathrm{b}, \mathrm{B}}$ & $2.86 \pm 0.13^{\mathrm{b}, \mathrm{A}}$ & $0.01 \pm 0.00^{\mathrm{a}, \mathrm{A}}$ & $0.04 \pm 0.00^{\mathrm{b}, \mathrm{A}}$ & nd & $2.91 \pm 0.13^{\mathrm{c}, \mathrm{A}}$ \\
\hline & Red-Violet & SP2 & $2.46 \pm 0.07^{\mathrm{a}, \mathrm{A}}$ & $11.42 \pm 0.14^{\mathrm{d}, \mathrm{B}}$ & $0.02 \pm 0.00^{\mathrm{b}, \mathrm{B}}$ & $2.16 \pm 0.05^{\mathrm{d}, \mathrm{B}}$ & $0.06 \pm 0.00^{\mathrm{a}}$ & $13.66 \pm 0.19^{\mathrm{e}, \mathrm{B}}$ \\
\hline
\end{tabular}

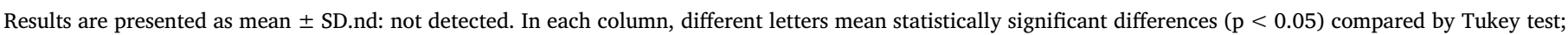

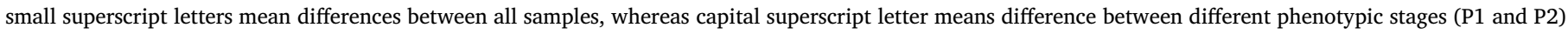
for the same species.

Overall, tocopherols profile was distinguished by plenty affluence of $\delta$-tocopherol $(8.59 \mathrm{~g} / 100 \mathrm{~g} \mathrm{fw})$ in $H$. strobilaceum and $\alpha$-tocopherol $(11.42 \mathrm{~g} / 100 \mathrm{~g} \mathrm{fw})$ in $S$. fruticosa. Indeed, many researchers have reported that $\alpha$-tocopherol is the most abundant isomer in halophytes and that these plants also contain an appreciable amount of $\delta$-tocopherol (Davy et al., 2001; Ksouri et al., 2012).

\subsection{PCA analysis}

As previously mentioned, halophytes are highly influenced by the environmental fluctuations, therefore, the analysed halophyte change their phenotypic stage as a strategy to be adapted to these conditions and avoid the excessive salt accumulation that generates real damage. This study aims to explore the nutritional and phytochemical composition of the studied halophytes leaves that change their colour from green to red-violet.

In order to characterize the three analysed halophytes and classify them according to their phenotypic stage, a multivariate analysis was applied, advisable due to the variability observed (Fig. 1). A principal component analysis (PCA) was performed reducing the multidimensional structure of the data, which provided a three-dimensional map for explaining the observed variance. The two components of the PCA performed explain $85.81 \%$ of the total variance (36.20 \% first, $32.55 \%$ second, and $17.06 \%$ third). All the studied samples were plotted on the reduced space of the two principal components (Fig. 1). The first principal component is highly and positively correlated to, total available carbohydrates $(0.3931)$ and total dietary fiber $(0.3424)$ and negatively and highly correlated with humidity $(-0.3315)$ total ashes (-0.3588) and sodium (-0.3952). The second principal component was strongly and positively correlated to ascorbic acid (0.4044) and MUFA $(0.3264)$ and negatively with total fat $(-0.3706)$ and proteins $(-0.3672)$, and SFA (-0.3227). And finally, the third principal component was highly and positively correlated to total tocopherols (0.6383) and PUFA (0.3641).

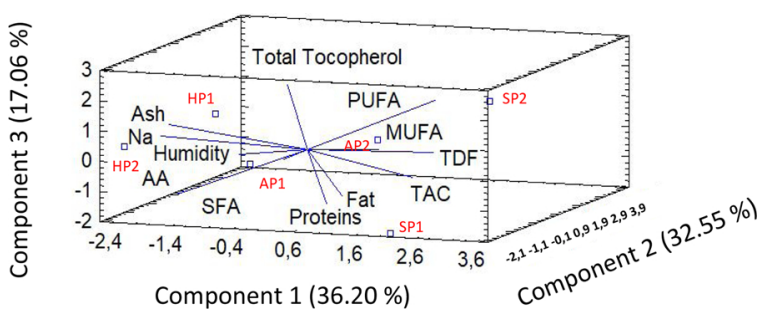

Fig. 1. Principal component analysis (PCA) projection of three principal components.

AA (Ascorbic acid), MUFA (Monounsaturated fatty acids), Na (Sodium), PUFA (Polyunsaturated fatty acids), SFA (Saturated fatty acids), TAC (Total available carbohydrates), TDF (Total dietary fiber). AP1 (Arthrocnemum indicum, Green phenotipic stage), AP2 (Arthrocnemum indicum, Red-Violet phenotipic stage), HP1 (Halocnemum strobilaceum, Green phenotipic stage), HP2 (Halocnemum strobilaceum, Red-violet phenotipic stage), SP1 (Suaeda fruticosa, Green phenotipic stage), SP2 (Suaeda fruticosa, Red-violet phenotipic stage).
All the studied halophytes are plotted on the reduced space of the two first principal components as it is shown in Fig.1. As it can be seen, Arthrocnemum green shoots (AP1, - 1.4457) as well as Halocnemum samples red-violet shoots, HP2 (-2.3333) are negatively characterized by first principal component (thus, with higher ashes and sodium content, as well as lower TAC and TDF), contrarily to Suaeda samples in both phenotypic stages SP1 (2.111) and SP2 (2.8642), which were positively correlated with this principal component. Arthrocnemum redviolet shoots (AP2, 3.0334) were highly and positively correlated with second components and therefore higher ascorbic acid content and lower total fat and proteins. And Halocnemum samples green shoots were positively correlated with the third component (HP1, 1.2804), which is characterized by a high total tocopherol and PUFA content.

According with the obtained results, we can conclude that regarding the nutritional composition of the different species and their corresponding different phenotypic stages, Arthrocnemum green shoots provide a higher carbohydrate content (TAC and TDF) but lower ashes and Na values, since this shoots were collected in spring period (lower soil salinity). While, Arthrocnemum red-violet shoots content a lower total fat and SFA content in order to limit the Na permeability though their membranes and maintain the correct plant homeostasis. Regarding Halocnemum samples, red-violet shoot present a similar tendency that Arthrocnemum green shoots, while Halocnemum green shoot were characterized by an important amount of total tocopherols content.

Although Suaeda samples present differences regarding their PUFA/ SFA ratio (among others), the PCA analysis do not show significant differences between both phenotypic stages since in both cases were positively characterized by the first component.

\section{Conclusions}

In conclusion, the studied shoots of wild Tunisian Amaranthaceae halophytes, namely $A$. indicum, $H$. strobilaceum, and $S$. fruticosa, presented an interesting nutritional profile. As expected, all of them presented high sodium content, being lower in green phenotypic, except in the case of Arthrocnemum samples, due to soil salinity conditions in summer in the harvesting area (salt mashes (Sebkha, Monastir). Although the harmful effects of abiotic constraint, the studied green or red-violet shoots can be considered as healthy food, rich in minerals, dietary fiber, and proteins, and poor in fats, with interesting index of lipid quality. As part of their physiological defence mechanism, the redviolet shoots, which were harvested in summer (when the salt marshes soil (Sebkha) where richest in $\mathrm{NaCl}$ ), present a lower amount of total fat and SFA content in order to limit the Na membrane permeability and maintain the normal plant homeostasis.

Thus, the studied halophytes could be considered as a good alternative to the conventional vegetables, due to their nutritional composition and their high disponibility, mainly in the aridand semi-arid region, such as Mediterranean countries and the Arabicgulf area. 


\section{Declaration of Competing Interest}

The author declare no conflict of interest

\section{CRediT authorship contribution statement}

Mariem Maatallah Zaier: Investigation, Writing - original draft. María Ciudad-Mulero: Writing - original draft. Montaña Cámara: Methodology, Writing - review \& editing. Carla Pereira: Investigation. Isabel C.F.R. Ferreira: Methodology, Writing - review \& editing. Lotfi Achour: Project administration, Resources. Adnen Kacem: Conceptualization, Supervision. Patricia Morales: Conceptualization, Supervision, Writing - review \& editing.

\section{Acknowledgements}

The authors are grateful to the ALIMNOVA Research group (UCM GR105/18) for financial support, as well as to Foundation for Science and Technology (FCT, Portugal) and FEDER under Programmer PT2020 for financial support to CIMO (UID/AGR/00690/2019). C. Pereira contract through the celebration of program-contract foreseen in No. 4, 5 and 6 of article $23^{\circ}$ of Decree-Law No. 57/2016, of 29th August, amended by Law No. 57/2017, of 19th July.

\section{References}

Abdelly, C., Barhoumi, Z., Ghnaya, T., Debez, A., Ben Hamed, K., Ksouri, R., Talbi, O., Zribi, F., Ouerghi, Z., Smaoui, A., 2006. Potential utilisation of halophytes for the rehabilitation and valorisation of salt-affected areas in Tunisia. In: Öztürk, M., Waisel, Y., Khan, M.A., Görk, G. (Eds.), Biosaline Agriculture and Salinity Tolerance in Plants. Birkhäuser Basel, pp. 163-172.

Ahanger, M.A., Tomar, N.S., Tittal, M., Argal, S., Agarwal, R.M., 2017. Plant growth under water/salt stress: ROS production; antioxidants and significance of added potassium under such conditions. Physiol. Mol. Biol. Plantas 23 (4), 731-744.

AOAC, 2000. Official Methods of Analysis, 17th edition. Association of Official Analytical Chemist International, Washington DC.

Atia, A., Rabhi, M., Debez, A., Abdelly, C., Gouia, H., Haouari, C.C., Smaoui, A., 2014. Ecophysiological aspects in 105 plants species of saline and arid environments in Tunisia. J. Arid Land 6 (6), 762-770.

Barreira, L., Resek, E., Rodrigues, M.J., Rocha, M.I., Pereira, H., Bandarra, N., Moreira da Silva, M., Varela, J., Custódio, L., 2017. Halophytes: gourmet food with nutritional health benefits? J. Food Compos. Anal. 59, 35-42.

Biondi, E., Casavecchia, S., Estrelles, E., Soriano, P., 2013. Halocnemum M. Bieb. vegetation in the Mediterranean Basin. Plant Biosystems - An Inter. J. Dealing Aspects Plant Biology 147 (3), 536-547.

Borah, S., Baruah, A.M., Das, A.K., Borah, J., 2009. Determination of mineral content in commonly consumed leafy vegetables. Food Anal. Methods 2 (3), 226-230.

Chau, C.F., Huang, Y.L., 2003. Comparison of the chemical composition and physicochemical properties of different fibers prepared from the peel of Citrus sinensis L. Cv. Liucheng. J. Agric. Food Chem. 51 (9), 2615-2618.

Cheeseman, J.M., 2013. The integration of activity in saline environments: problems and perspectives. Funct. Plant Biol. 40, 759-774.

Chen, M., Yang, Z., Liu, J., Zhu, T., Wei, X., Fan, H., Wang, B., 2018. Adaptation mechanism of salt excluders under saline conditions and its applications. Int. J. Mol. Sci. 19 (11), 3668.

Davy, A.J., Bishop, G.F., Costa, C.S.B., 2001. Salicornia L. (Salicornia pusilla J. Woods, S. Ramosissima J. Woods, S. Europaea L., S. Obscura P.W. Ball \& Tutin, S. Nitens. P.W. Ball \& Tutin, S. Fragilis P.W. Ball \& Tutin and S. Dolichostachya moss). J. Ecol. 89 (4), 681-707.

Díaz, F.J., Benes, S.E., Grattan, S.R., 2013. Field performance of halophytic species under irrigation with saline drainage water in the San Joaquin Valley of California. Agric. Water Manag. 118, 59-69.

Doddema, H., Saad Eddin, R., Mahasneh, A., 1986. Effects of seasonal changes of soil salinity and soil nitrogen on the N-metabolism of the halophyte Arthrocnemum fruticosum (L.). Moq. Plant Soil 92 (2), 279-293.

Duarte, B., Carreiras, J., Pérez-Romero, J.A., Mateos-Naranjo, E., Redondo-Gómez, S., Matos, A.R., Marques, J.C., Caçador, I., 2018. Halophyte fatty acids as biomarkers of anthropogenic-driven contamination in Mediterranean marshes: sentinel species survey and development of an integrated biomarker response (IBR) index. Ecol. Indic. 87, 86-96.

EFSA Panel on Dietetic Products, Nutrition, and Allergies (NDA), 2010. Scientific Opinion on Dietary Reference Values for carbohydrates and dietary fibre. Efsa J. 8 (3), 77. https://doi.org/10.2903/j.efsa.2010.1462. 1462.

European Parliament \& Council of the European Union, 2006. Regulation (EC) No 1924/ 2006 of the European Parliament and of the Council of 20 December 2006 on nutrition and health claims made on foods. Off. J. Eur. Union L12/3:18 (18/01/2007).

European Parliament \& Council of the European Union, 2011. Regulation (EU) No 1169/ 2011 of the European Parliament and of the Council of 25 October 2011 on the provision of food information to consumers. Off. J. Eur. Union L304/18:63 (22/11/ 2011).

Fernandez, M.L., West, K.L., 2005. Mechanisms by which dietary fatty acids modulate plasma lipids. J. Nutr. 135 (9), 2075-2078.

Flowers, T.J., 1985. Physiology of halophytes. Plant Soil 89, 41-56.

Flowers, T.J., Colmer, T.D., 2008. Salinity tolerance in halophytes. New Phytol. 179 (4), 945-963.

Flowers, T.J., Galal, H.K., Bromham, L., 2010. Evolution of halophytes: multiple origins of salt tolerance in land plants. Funct. Plant Biol. 37 (7), 604-612.

Fuller, S., Beck, E., Salman, H., Tapsell, L., 2016. New horizons for the study of dietary Fiber and health: a review. Plant Foods Hum. Nutr. 71 (1), 1-12.

Gairola, S., Bhatt, A., El-Keblawy, A., 2015. A perspective on potential use of halophytes for reclamation of salt-affected lands. Wulfenia J. 22 (1), 88-97.

Ghazanfar, S.A., Altundag, E., Yaprak, A.E., Osborne, J., Tug, G.N., Vural, M., 2014. Halophytes of Southwest Asia. Tasks Veg. Sci. 47, 105-133.

Glenn, E.P., Brown, J.J., Blumwald, E., 1999. Salt tolerance and crop potential of halophytes. Crit. Rev. Plant Sci. 18 (2), 227-255.

Guarrera, P.M., Salerno, G., Caneva, G., 2006. Food, flavouring and feed plant traditions in the Tyrrhenian sector of Basilicata, Italy. J. Ethnobiol. Ethnomed. 2, 37.

Guil Guerrero, J., Giménez Martínez, J., Torija Isasa, M.E., 1998. Mineral nutrient composition of edible wild plants. J. Food Compos. Anal. 11 (4), 322-328.

Hameed, A., Khan, M., 2011. Halophytes: biology and economic potentials. Karachi Univ. J. Sci. 39 (1), 40-44.

Hameed, A., Hussain, T., Gulzar, S., Aziz, I., Gul, B., Khan, M.A., 2012. Salt tolerance of a cash crop halophyte Suaeda fruticosa: biochemical responses to salt and exogenous chemical treatments. Acta Physiol. Plant. 34 (6), 2331-2340.

Hasanuzzaman, M., Nahar, K., Alam, M.M., Bhowmik, P.C., Hossain, M.A., Rahman, M.M., Prasad, M.N.V., Ozturk, M., Fujita, M., 2014. Potential use of halophytes to remediate saline soils. Biomed Res. Int. 1-12.

Hayakawa, K., Agarie, S., 2010. Physiological roles of betacyanin in a halophyte, Suaeda japonica makino. Plant Prod. Sci. 13 (4), 351-359.

Hounsome, N., Hounsome, B., 2011. Biochemistry of vegetables: Major classes of primary (carbohydrates, amino acids, fatty acids, vitamins, and organic acids) and secondary metabolites (terpenoids, phenolics, alkaloids, and sulfur-containing compounds) in vegetables. In: Sinha, N.K. (Ed.), Handbook of Vegetables and Vegetable Processing, https://doi.org/10.1002/9780470958346. ch2.

Khan, M.A., Qaiser, M., 2006. Halophytes of Pakistan: characteristics, distribution and potential economic usages. In: In: Khan, M.A., Böer, B., Kust, G.S., Barth, H.J. (Eds.), Tasks for Vegetation Science 42 Sabkha Ecosystems. Springer, Dordrecht.

Kim, S.H., Yan, Y.B., Zhou, H.M., 2006. Role of osmolytes as chemical chaperones during the refolding of aminoacylase. Biochem. Cell Biol. 84 (1), 30-38.

Ksouri, R., Ksouri, W.M., Jallali, I., Debez, A., Magné, C., Hiroko, I., Abdelly, C., 2012. Medicinal halophytes: potent source of health promoting biomolecules with medical, nutraceutical and food applications. Crit. Rev. Biotechnol. 32 (4), 289-326.

Latimer, G.W., 2012. Official Methods of Analysis of AOAC International, 18th ed. EEUU, Gaithersburg.

Lokhande, V.H., Suprasanna, P., 2012. Prospects of halophytes in understanding and managing abiotic stress tolerance. In: Ahmad, P., Prasad, M. (Eds.), Environmental Adaptations and Stress Tolerance of Plants in the Era of Climate Change. Springer, New York, NY.

Morales, P., Carvalho, A.M., Sánchez-Mata, M.C., Cámara, M., Molina, M., Ferreira, I.C.F.R., 2012. Tocopherol composition and antioxidant activity of Spanish wild vegetables. Genet. Resour. Crop Evol. 59 (5), 851-863.

Morales, P., Ferreira, I.C., Carvalho, A.M., Fernández-Ruiz, V., Sánchez-Mata, M.C., Cámara, M., Morales, R., Tardío, J., 2013. Wild edible fruits as a potential source of phytochemicals with capacity to inhibit lipid peroxidation. Euro. J. Lipid Sci. Technol. 115 (2), 176-185.

Munns, R., Tester, M., 2008. Mechanisms of salinity tolerance. Annu. Rev. Plant Biol. 59 (1), 651-681.

Najjaa, H., Boubakri, A., Arfa, A.B., Zouari, N., Neffati, M., 2018. Salinity and drought stresses improve antioxidant potential of Allium roseum L., an edible medicinal plant. Acta Physiol. Plant. 40, 195.

Osborne, D., Voogt, P., 1986. In: Acribia, S.A. (Ed.), Analysis of Food Nutrients, Zaragoza, Spain.

Parida, A., Das, A.B., Das, P., 2002. $\mathrm{NaCl}$ stress causes changes in photosynthetic pigments, proteins, and other metabolic components in the leaves of a true mangrove, Bruguiera parviflora, in hydroponic cultures. J. Plant Biol. 45 (1), 28-36.

Punna, R., Paruchuri, U.R., 2004. Effect of maturity and processing on total, insoluble and soluble dietary fiber contents of Indian green leafy vegetables. Int. J. Food Sci. Nutr. 55 (7), 561-567.

Qasim, M., Gulzar, S., Khan, M.A., 2011. Halophytes as medicinal plants. In: In NAM Meeting in Denizli. Turkey.

Rangani, J., Kumari, A., Patel, M., Brahmbhatt, H., Parida, A.K., 2019. Phytochemical profiling, polyphenol composition, and antioxidant activity of the leaf extract from the medicinal halophyte Thespesia populnea reveal a potential source of bioactive compounds and nutraceuticals. J. Food Biochem. 43, 12731.

Rocha, M., Rodrigues, M., Pereira, C., Pereira, H., da Silva, M., Neng, N., da, R., Nogueira, J., Varela, J., Barreira, L., Custódio, L., 2017. Biochemical profile and in vitro neuroprotective properties of Carpobrotus edulis L., a medicinal and edible halophyte native to the coast of South Africa. South Afr. J. Bot. 111, 222-231.

Rodríguez, R., Jiménez, A., Fernández-Bolaños, J., Guillén, R., Heredia, A., 2006. Dietary Fibre from vegetable products as source of functional ingredients. Trends Food Sci. Technol. 17 (1), 3-15.

Rodríguez, L.H., Morales, D.A., Rodríguez, E.R., Romero, C.D., 2011. Minerals and trace elements in a collection of wheat landraces from the Canary Islands. J. Food Compos. Anal. 24 (8), 1081-1090. 
Rozentsvet, O.A., Nesterov, V.N., Sinyutina, N.F., 2012. The effect of copper ions on the lipid composition of subcellular membranes in Hydrilla verticillata. Chemosphere 89 (1), 108-113.

Samson, T., 2017. Weather Tunisia 20. pp. 2019. Retrieved Marchfrom 2017. https:// www.historique-meteo.net/afrique/tunisie/2017/.

Siddiq, M., 2018. Handbook of Vegetables and Vegetable Processing. John Wiley \& Sons. Slama, I., Ghnaya, T., Messedi, D., Hessini, K., Labidi, N., Savoure, A., Abdelly, C., 2007. Effect of sodium chloride on the response of the halophyte species Sesuvium portulacastrum grown in mannitol-induced water stress. J. Plant Res. 120 (2), 291-299.

Slama, I., Abdelly, C., Bouchereau, A., Flowers, T., Savoure, A., 2015. Diversity, distribution and roles of osmoprotective compounds accumulated in halophytes under abiotic stress. Ann. Bot. 115 (3), 433-447.

Sui, N., Li, M., Li, K., Song, J., Wang, B.S., 2010. Increase in unsaturated fatty acids in membrane lipids of Suaeda salsa L. Enhances protection of photosystem II under high salinity. Photosynthetica 48 (4), 623-629.

Sun, H.X., Zhou, D.W., Zhao, C.S., Wang, M.L., Zhong, R.Z., Liu, H.W., 2012. Evaluation of yield and chemical composition of a halophyte (Suaeda glauca) and its feeding value for lambs. Grass Forage Sci. 67, 153-161.

Tipirdamaz, R., Gagneul, D., Duhazé, C., Aïnouche, A., Monnier, C., Özkum, D., Larher, F., 2006. Clustering of halophytes from an inland salt marsh in Turkey according to their ability to accumulate sodium and nitrogenous osmolytes. Environ. Exp. Bot. 57, 139-153.

Ulbricht, T., Southgate, D., 1991. Coronary heart disease: seven dietary factors. Lancet 338 (8773), 985-992.

Wanders, A.J., Alssema, M., de Koning, E.J.P., le Cessie, S., de Vries, J.H., Zock, P.L.
Rosendaal, F.R., Heijer, M.D., de Mutsert, R., 2017. Fatty acid intake and its dietary sources in relation with markers of type 2 diabetes risk: the NEO study. Eur. J. Clin. Nutr. 71 (2), 245-251.

Wang, C., Li, J., Yuan, M., 2007. Salt tolerance requires cortical microtubule reorganization in Arabidopsis. Plant Cell Physiol. 48, 1534-1547.

Weber, D.J., Ansari, R., Gul, B., Ajmal Khan, M., 2007. Potential of halophytes as source of edible oil. J. Arid Environ. 68 (2), 315-321.

Win, K.T., Oo, A.Z., 2017. Salt-stress-induced changes in protein profiles in two black gram (Vigna mungo L.) varieties differing salinity tolerance. Adv. Plants Agric. Res. 7 (1), 206-210.

Yildiz, M., 2007. Two-dimensional electrophoretic analysis of soluble leaf proteins of a salt-sensitive (Triticum aestivum) and a salt-tolerant (T. durum) cultivar in response to $\mathrm{NaCl}$ stress. J. Integr. Plant Biol. 49 (7), 975-981.

Zaruyk, R.A., Baalbaki, R., 1996. Inula crithmoides: a candidate plant for saline agriculture. Arid. Soil Res. Rehabil. 10 (3), 213-223.

Zhang, J.L., Flowers, T.J., Wang, S.M., 2010. Mechanisms of sodium uptake by roots of higher plants. Plant Soil 326 (1-2), 45-60.

Zhao, K., Song, J., Feng, G., Zhao, M., Liu, J., 2011. Species, types, distribution, and economic potential of halophytes in China. Plant Soil 342 (1-2), 495-509.

Zhu, J.K., 2002. Salt and drought stress signal transduction implants. Annu. Rev. Plant Biol. 53 (1), 247-273.

Zhu, T., Row, K.H., 2010. Extraction and determination of $\beta$-Sitosterol from Salicornia herbacea L. Using monolithic cartridge. Chromatographia 71 (11-12), 981-985.

USDA (2016). Retrieved July 4, 2019, from http://www.nal.usda.gov/fnic/foodcomp/ Data/. 